\title{
EDUCATION FOR LEISURE IN ELEMENTARY SCHOOL: THE USE OF COMIC BOOKS IN PHYSICAL EDUCATION CLASSES
}

\author{
Cinthia Lopes da Silva* \\ Silvio Rossi Filho** \\ Priscilla Pinto Costa da Silva*** \\ Gisele Maria Schwartz***** \\ Marcio Ferreira de Soura***** \\ Adalberto dos Santos Soura******* \\ Adriano Scalzitti******* \\ Rosiane Pillon ${ }^{* * * * * * * *}$ \\ Luciene Ferreira da Silva******** \\ Ana Carolina Capellini Rigoni ${ }^{* * * * * * * * * *}$
}

\begin{abstract}
In Brazil, many students dislike Physical Education classes because of content repetition, dissatisfactory curricular organization, among other factors. This work aims at assessing the efficiency of a proposal for Physical Education classes, which includes contents of physical activities and the use of comic books. This is a qualitative study and both bibliographic and field researches were carried out. Ten classes were held to a group of ninth graders from a public school in the city of Piracicaba/SP/Brazil. We found that the use of comic books as a teaching resource is effective: it portrays the experiences that the students, felt and mediated through their "rational" and "sensitive" knowledge about physical activities.
\end{abstract}

Keywords: Leisure activities, Physical Education, Comic Books.

\footnotetext{
* Physical Education PhD at Universidade Estadual de Campinas (UNICAMP). Professor at Universidade Metodista de Piracicaba (UNIMEP). Email: cinthia.silva@unimep.br ORCID: 0000-0002-7979-0337.

${ }^{* *}$ Human Movement Sciences Master at UNIMEP. Physical Education teacher in Capivari-SP/Brazil public school. Email: silviorossifilho@gmail.com ORCID: 0000-0003-2251-1728.

*** Physical Education PhD at Universidade de Pernambuco/Universidade Federal da Paraíba. Professor at Universidade Federal do Rio Grande do Norte (UFRN). Email: laprisci@gmail.com ORCID: 0000-0001-6200-5614.

**** Psycology PhD at Universidade de São Paulo (USP). Professor at Universidade Estadual Paulista "Júlio de Mesquita Filho" (UNESP-Rio Claro). Email: gisele.schwartz@unesp.br ORCID: 0000-0001-9103-8853.

***** Human Movement Sciences PhD at UNIMEP. Physical Education teacher in Cosmópolis-SP/Brazil public school. Email:marciofsza@gmail.com ORCID:0000-0002-8273-7959.

****** Physical Education PhD at UNICAMP. Professor at Universidade Federal de São Paulo - Guarulhos (UNIFESPGuarulhos). Email: neysouza11@hotmail.com ORCID: 0000-0003-3782-6298.

******* Education PhD at UNIMEP. Geography teacher in Piracicaba-SP/Brazil public school.

Email: adrianoscalzitti@prof.educacao.sp.gov.br ORCID: 0000-0001-7252-221X.

******** Physical Education Graduate at UNIMEP. Master student in Human Movement Sciences Program - UNIMEP.

Email: ro pillon@hotmail.com ORCID: 0000-0002-3855-9913.

*********Physical Education PhD at UNICAMP. Professor at Universidade Estadual Paulista "Júlio de Mesquita Filho" (UNESP-Bauru). Email: silvalucienef@gmail.com ORCID: 0000-0003-2646-0235.

********** Physical Education PhD at UNICAMP. Professor at Universidade Federal do Espírito Santo (UFES).

Email: anacarolinarigoni@yahoo.com.br ORCID: 0000-0002-9757-6860.
} 


\title{
EDUCAÇÃO PARA O LAZER NO ENSINO FUNDAMENTAL: O USO DE HISTÓRIAS EM QUADRINHOS NAS AULAS DE EDUCAÇÃO FÍSICA
}

\begin{abstract}
RESUMO: No Brasil, muitos alunos não gostam das aulas de Educação Física devido à repetição de conteúdos, organização curricular insatisfatória, entre outros fatores. Este trabalho objetivou avaliar a eficácia de uma proposta de aulas de Educação Física que contempla conteúdos de práticas corporais e a utilização de histórias em quadrinhos (HQ). Este estudo é qualitativo e foram realizadas pesquisas bibliográficas e de campo. Dez aulas foram ministradas para uma turma de alunos do nono ano de uma escola pública da cidade de Piracicaba / SP / Brasil. Nossos achados apontam que a utilização de HQ como recurso didático é potente na medida em que retrata as experiências vividas pelos alunos, sentidas e mediadas por meio de seus conhecimentos "racionais" e "sensíveis" sobre as práticas corporais.
\end{abstract}

Palavras-chave: Atividades de lazer, Educação Física, Histórias em quadrinhos.

\section{Introduction}

Several studies have pointed to the failure of school in recent years (ARROYO, 2003; COHEN, 2006; NAVARRO, GERVAI, NAKAYAMA \& PRAD, 2016). High levels of repetition and school dropout translate the low quality of Brazilian Basic Education. The motivations are many and diverse, affecting Physical Education classes (repetition of contents, unsatisfactory curricular organization, etc.), according to some authors: Darido (2004), Fortes et al. (2012), Oliveira (2010), Tenório and Lopes da Silva (2015), Carvalho and Lopes da Silva (2015).

The problem is aggravated when some research data on the practice of Brazilian physical activity are observed, such as the recent Diesporte research (BRASIL, 2017), in which a significant number of people do not practice any type of physical activity / body practice in the available time. 8,902 people were interviewed. The data were based on a projection of the Brazilian population by region, gender and age groups, made by the IBGE for the year 2013, of approximately 146,748,000 Brazilians, equivalent to the population between 14 and 75 years. The results were as follows:

Practitioners of physical activities: $28.5 \%$

- Practitioners of sports: $25.6 \%$

- Sedentary: $45.9 \%$

- Sedentarism by gender: $41.2 \%$ (men) and $50.4 \%$ (women)

- Sedentary by age group: 15 to 19 years $(32.7 \%) ; 20$ to 24 years $(38.1 \%) ; 25$ to 34 years $(40.7 \%) ; 35$ to 44 years (46.4\%); 45 to 54 years $(53.5 \%)$; 55 to 64 years old (56.5\%); 65 to 74 years $(64.4 \%)$.

- Abandonment of the practice of physical activity and sports practice by region of the country, by age range, with the highest indices being from 16 to 24 years: northern region (49.7\%), midwest region (45.7\%), northeast region (46.4\%), southern region (41.8\%), southeast region (44.5\%).

Although the values presented are more positive than previous research, on the practice of physical activities (MIRANDA, 2011), since in the year of 2013, 54.1\% of the Brazilian population 
practiced some type of physical activity percentage of those who do not practice them (45.9\%). It can be noted from this most recent study (BRASIL, 2017) that the profile of practitioners continues to be the same as in previous research, in which the lowest percentages of sedentarism are younger men and the lowest dropout rates of physical activities and sports in the range of 16 to 24 years are from the south and southeast regions. That is, the profile of the largest practicing group continues to be that of men, young people and with better conditions of life.

This problem involving people's access to physical activities in Brazil is due, both to issues related to sports and leisure public policies, and experiences people have had throughout their lives that did not provide them with the construction of appreciate sports, games, dance, etc., elements that could be practiced in the free time throughout life. That is, students may not have access to adequate knowledge of physical activities at school and may not have this opportunity throughout life, from public sports and leisure projects.

The biological consequences of this are various (heart problems, obesity, hypertension, etc.), due to the non-performance of physical activities in everyday life, but there is also a loss, which is not always considered, not the development of the knowledge about the body and the elements of the bodily culture of movement, which can cause the subjects not to understand themselves, their sensibility, their emotions, which are felt and manifested bodily. Thus, it is necessary to look for methodological elements and resources that are an incentive for students to develop a taste for knowledge in school, and in particular in Physical Education classes, that feel motivated to participate in the corporal experiences proposed from physical activities. Thus, to bring to class the subject of physical activities and the construction of comic books can be a way of dealing with data presented about school failure and the percentages of people who do not have integrated in their everyday lifes the practice of physical activities. Some publications relationship with this research are: Lopes da Silva (2018a, 2018b), Lopes da Silva et al. (2019a, 2019b, 2019c).

\section{Objective}

This work has the objective of assessing the efficiency of a proposal for Physical Education classes, which includes various contents of bodily culture of movement and the use of comic books.

\section{Method}

Both bibliographic and field researches were carried out and this is a qualitative study, according Minayo (1994). A bibliographic research was carried out in libraries of Brazilian public universities, in the Scielo database and in the Brazilian Digital Library of Theses and Dissertations (BDTD). The period of 
the bibliographical survey was from March to May 2018 and texts published from 2014 until May 2018 were selected.

Field research was also carried out at a public school in the city of Piracicaba, state of São Paulo / Brazil, along with a class from the 9th grade of Elementary School. Within 10 given classes, 21 students out of 37 participated in the research, being 9 girls and 12 boys. The classes were scheduled according to what is described below:

- Class \#1: students completed the evaluation questionnaire in relation to what they know about "leisure, education and comics", and then the teacher introduced them to the idea of including technology in the classes of Physical Education, from the construction of comic book, having as purpose the education for leisure.

- Class \#2: guidelines on building comics from newspaper clippings and magazines or drawing.

- Class \#3: discussion / experience of the theme "Adventure activities in nature, care for the environment and education for leisure in Elementary School".

- Class \#4: Construction of comic book, having as theme the previous class (3).

- Class \#5: discussion / experience of the theme "Physical activities, community and education for leisure in Elementary School".

- Class \#6: Construction of comic book, having as theme the previous class (\#5).

- Class \#7: discussion / experience "comic book of superheroes and education for leisure in elementary school".

- Class \#8: comic book construction, having as theme the previous class (\#7).

- Class \#9: Reading and discussion of constructed comic book.

- Class \#10: Students completed a questionnaire evaluating what they could understand about the pedagogical experience and closed the discussions.

An example of the classes it is the class \#5 about discussion / experience of the theme "Physical activities, community and education for leisure in Elementary School” and class \#6 - Construction of a comic book, having as theme the previous class (\#5):

The objectives of class \#5 were:

1- To understand the relationship between physical activities, leisure and community;

2- To experience an activity to each element of bodily culture of movement (sports, gymnastics, fight, game and dance). 
The objective of class \#6 was the construction of a comic book, having as theme the previous class (\#5).

In this paper we described and analysed only class \#5 and one of the comic books from class \#6. In the analysis, it was done an interpretation based in Minayo (1994) and in the bibliographic research. We also applied a questionnaire to evaluate what the students learned in the classes. The analysis of the questionnaire was based on a bibliographic research as well. For the purposes of this paper we will consider the analysis only of the question \#4 - What have you learned in our classes? The research was approved by the Research Ethics Committee at Methodist University of Piracicaba, Brazil, under protocol 2.641.621, process CAAE 87190218.3.0000.5507.

\section{Results and discussion}

The pedagogical experiment made possible for the students of this investigation: 1 - the education for leisure, 2- the awakening to the enjoyment and knowledge about elements of the bodily culture of movement, 3- the access to some of the leisure contents presented here, mainly by the physical and artistic activities, and 4- also by the experiences in class and the construction of comic books.

The class called "Bodily practices and physical activities, community and education for leisure in Elementary School' presented as follows happened on Sept.25, 2018. The planning of this lesson is in the table below: Objective:

Understand the relation of bodily practices with physical activities, leisure and community: experience an activity for each element of the bodily culture (sports, gymnastics, fights, games and dances).

Content of the class:

Bodily practices.

Objects used:

Rackets and badminton shuttlecocks, hoops and artistic gymnastics tape, swords made out of foam sticks, long pieces of ropes and a stereo.

Activity 1 procedure:

Sitting in a circle, the teacher talked to the students about the relation of bodily practices and its relation with physical activity, leisure and community.

Activity 2 procedure:

Five stations were made in order to represent each one of the big groups of bodily practices (sports, gymnastics, fights, games and dances). After that, the teacher explained and demonstrated the activities 
of each station. Therefore, five groups were formed and each one of them started in a certain station. A certain amount of time was determined per station (06 minutes), so the activity was finished at the moment in which the groups had experienced all the stations. The activities in the stations were the following:

- SPORTS (Badminton): In pairs, the students of this station experienced a badminton match with adapted rules.

- GYMNASTICS (Artistic gymnastics): Hoops and tapes were given to the students so they could experience and feel the bodily movements with these objects.

- FIGHTS (Fencing): In this station, the teacher divided the students in groups of three so one student was the umpire and the other two fought with swords made out of foam sticks. A limited space was defined for the fight so the fencers could only move in that place. During the fight, in order to score, one fencer could hit any part of the opponent's body, except for the head. However, the 'umpire' student could only validate the score if the blow from student " $A$ " hit student "B" first. When they both got hit at the same time, nobody scored. After a certain amount of time, the 'umpire' student became one of the fencers so another fencer could be the umpire and so forth.

- GAMES AND CHILD PLAY (games with ropes): In this station, the students had long ropes so they could play different kids' games such as “zerinho"; "reloginho"; "Um homem bateu em minha porta...", "Salada saladinha..."; etc.

- DANCE (free dancing): In this station, a stereo played a list of songs suggested by the students in the previous class. They should just dance to the beat while creating and sharing dance steps.

Activity 3 procedure:

At the end, the teacher asked the students about the positive and negative aspects of each class.

\section{Evaluation:}

Students showed understanding of the practice of all activities. Observation of students' involvement in the activities.

The class went as planned because the preparation of the dance stations (pre class) and also the other stations during class were a success. The students participated in all the activities within the proposed time frame thus fulfilling the proposed objectives. 
One thing to highlight is that only one of the students from the group had previously participated in some of the activities from the lesson taught. According to this student, he had already participated in some of the activities when he studied at a private school. Therefore, all the other students had no knowledge of any of the proposed activities in Physical Education class.

As it happens in many cases at public schools in the state of São Paulo, the theory of bodily practices is taught in class but rarely experienced by the students because the bodily practices are not part of the local and/or regional culture. In other words, the students sit in class, copy content from the blackboard, answer questions from their Physical Education books but do not often put in practice the bodily practices which are learnt.

During class, we could observe that two out of the five proposed activities were greatly enjoyed by most of the students: badminton and artistic gymnastics tape. In the case of badminton, boys and girls were equally interested and did not want to stop playing even after the class had ended. Their interest was so great that two students approached the professor-researcher to ask how much the rackets and shuttlecock cost.

When the students were sitting in a circle, they did not make many comments about the classes, but they said that they had enjoyed the activities, mainly badminton and artistic gymnastics tape (as it had been observed during class). One of the students said that "he not only liked soccer".

It is interesting to see the student who said he liked other things rather than soccer, which shows how soccer is an integral part of the contents in Physical Education classes and that was his main experience while in school. Soccer is present in sport content in the main national documents about Physical Education in schools: PCN's (BRASIL, 1997) and BNCC (BRASIL, 2016).

The problem can occur when there is the prevalence of sporting of Physical Education. According to Tenório and Lopes da Silva (2013), one of the main factors which drive students away from Physical Education classes is when the work is only focused on sport content, ignoring other manifestations of bodily culture of movement (fights, bodily practices of adventure in the outdoors, gymnastics and dance). In other words, there is a lack of diversified content.

This fact can limit the student because there is access to a very limited content in Physical Education (in this case sport), and the student is deprived of a range of many possibilities of bodily practices from which he/she could greatly benefit as an activity in the context of leisure throughout his/her life, and depending on the case, it could also be a profession.

In fact, the experience of the lesson showed a very active involvement from the students, and mainly from the ones who did not usually participate in the practical activities as actively as they should. That is to say that such interest could be the result of a more diversified lesson with other manifestations of bodily culture of movement, confirming the considerations of Tenório and Lopes da Silva (2013), about the importance of amplifying the range of activities in the context of leisure. 
Therefore, the proposed lesson provided the students with the construction of knowledge about the bodily culture of movement (related to the practices of fencing, badminton, artistic gymnastics tape, games and dances). This pedagogical action is in compliance with the considerations of Daolio (1994) and Marcellino (2004), which provide a network of knowledge so that the students may enjoy the physical and sport content of leisure throughout their lives in order to achieve critical and creative levels.

The following are images of the production of comic books by a group of students, on the theme of the lesson:

Figure 1

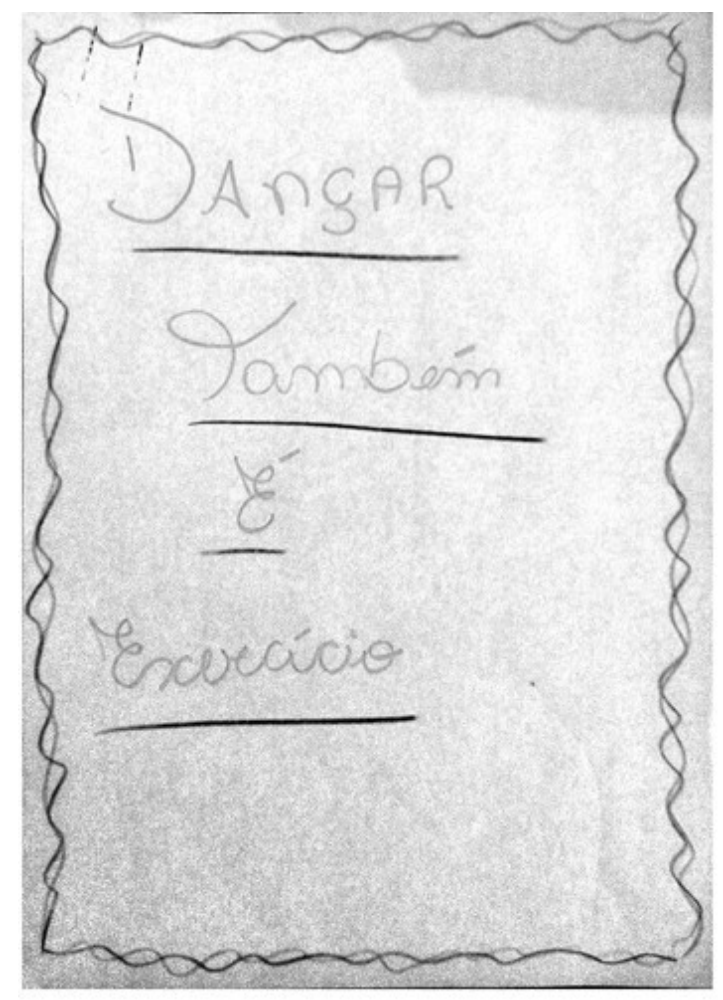

Research data

Translation: "Dance is an exercise too" 
Figure 2

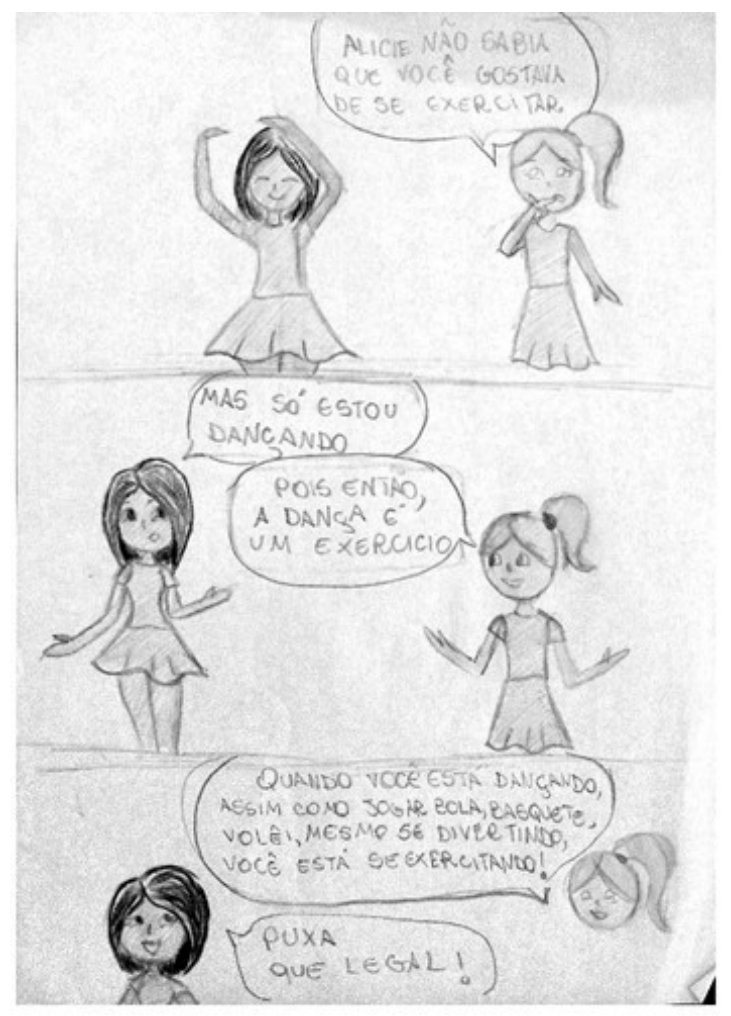

Research data

\section{Translation:}

Bubble 1: "Alice I didn't know you like to exercise"

Bubble 2: "But I am only dancing"

Bubble 3: "So, the dance is an exercise"

Bubble 4: "When you are dancing, the same as playing soccer, basketball, volleyball, even having fun you are also exercising."

Bubble 5: "Wow, great!" 
Figure 3

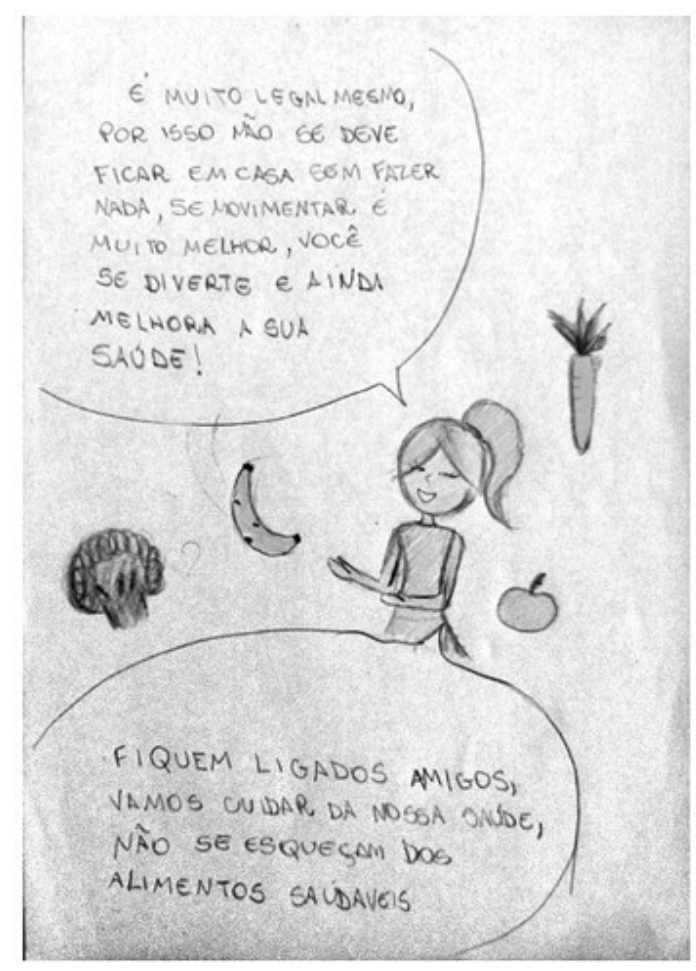

Research data

\section{Translation:}

Top bubble: "It's really very cool, that is why you shouldn't stay at home doing nothing. To move is much better, you have fun and also improve your health"

Bottom bubble: "Stay tuned friends, let's take care of our health, don't forget the healthy foods"

The constructed comic book shows that the group of students understood the purpose of the lesson, that other elements of the bodily culture of movement are part of the Physical Education classes and not exclusively the sport. Dance is portrayed as an activity, which is called by the students "exercise". It's to be performed in the free time, confirmed when, in figure 3, the students affirm "(...) you shouldn't stay at home doing anything", mentioning fun and health. Thus, students express the relationship between the element of bodily culture of movement - dance, leisure (fun and free time) and health, a consequence of the inclusion of such a practice in everyday life. This is a positive view about dance and represents a new knowledge produced by the students, based on Educational Communication (FERRÉS PRATS, 2014). 
The students also answered a questionnaire, whose answers to question 4 - What did you learn in our classes? - are set out below:

\section{Chart 1 - What have you learned in our classes?}

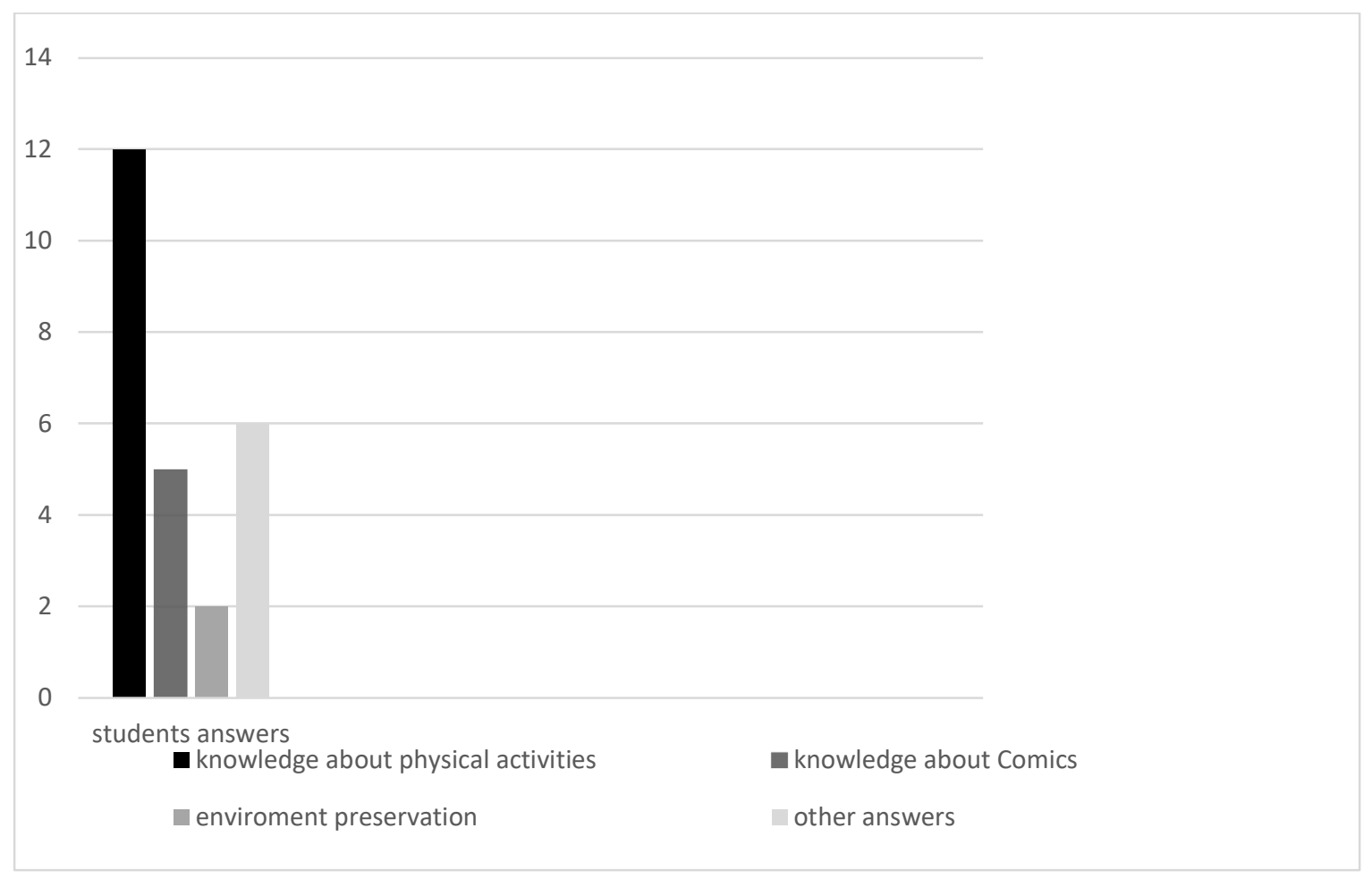

Research data

Most of the students (\# 01, 04, 07, 08, 11, 14, 16, 18, 19, 20 and 21) showed that they understood the discussions about knowledge on physical activities. This learning is related to new practices, such as fencing, badminton, le parkour, that is, activities that were part of the present study, as well as related to the development of abilities highlighted in the answers "to move", "to do exercises". In this skill issue, several students commented that they learned to walk in the slackline and handle the badminton racket, among other elements of bodily culture of movement.

In this case, the pedagogical experience enabled the students to access the knowledge related to the body and the elements of the body culture of movement, as well as providing opportunities to know and reflect critically on the contents. Thus, the students had the opportunity to experience and appreciate the physical activities, constructing the possibility of continuing to practice some or several of these activities in their free time, meeting the assumptions of education for leisure (MARCELLINO, 2004). Therefore, we can consider that one of the purposes of the pedagogical proposal ruled on education for leisure was achieved in this experiment because it provided the students with the construction of the taste for practice of sports, games, dance and so on. These elements can be practiced in their free time 
throughout their lives. In addition to the physiological benefits, helping to prevent cardiac conditions, obesity, high blood pressure, etc, the habit of bodily practices and physical activities promote the development of knowledge about the body and the bodily cultural elements of movement, making the participants more aware of themselves, their sensitivities and emotions, which are felt and manifested in the body. These data correspond to the studies of Fronza (2016), who analysed a research with the use of comic books in History classes and the presupposed of Educational Communication (FERRÉS PRATS, 2014).

Thereby, the pedagogical proposal highlights the necessity for pursuing elements and methodological resources which encourage the students to develop the taste for knowledge at school and, in particular, in Physical Education classes. We reiterate the importance of feeling motivated and engaged to participate in the proposed bodily experiences from the bodily practices and physical activities.

Another answer given by the students ( $\mathrm{n}^{\circ} 08,10,16,20$ and 21) was about the construction of knowledge related to the comic books (artistic cultural content of leisure), which can be enjoyed as an activity in the leisure context and/or awaken an interest for a professional activity related to comic books. This is common in the answers "make comic books", "formulate comic books", "art". This has occurred because Physical Education at school has its focus on education for leisure. Consequently, it works with other leisure contents beyond the physical/sport ones, even knowing that this content represents a remarkable specificity in the field of Physical Education and it must be the most worked on aspect during the school year.

Finally, the answer "nature is not only trees and the woods, but also the place where we live in" demonstrates that the knowledge of the students ( $\mathrm{n}^{\circ} 02$ and 03 ) constructed in the research classes was about the preservation of the environment, which does not only consist of worrying about natural resources such as rivers and species that are in danger of extinction, but also about our homes, daily places, be them natural or artificial such as squares, courts, fields, skateboard or bicycle lanes, etc, which are, in most cases, public spaces used for activities in the context of leisure, and which are the target of depredation due to bad maintenance, vandalism or neglect from the public policies harm the quality of leisure experiences from the population.

Students $n^{\circ}$ 05, 06, 09, 12, 13 and 17 answered the question with "many things"; "several things". Therefore, we considered such answers a little vague and in order to have a more thorough analysis, it is necessary to consider the answers of the same students about other questions (for instance, question 05 - What have you learned about the adventure activities in the outdoors?; and question 06 - What have you learned about the bodily practices and physical activities?) in order to identify more precisely how the construction of knowledge happens for those students. However, considering the present work, we chose question 04, but a more thorough analysis about the other answers can be carried out in other works. 


\section{Final considerations}

We could observe from this research that comic books can become a very interesting and effective resource for teaching. Once these resources are introduced in the school context, in Physical Education lessons, they can potentialize and enable students access to knowledge. Considering the arguments from the several researches which support themselves, be them in the Human Sciences, or Educational Communication and Neuroscience, and also in the leisure studies, we have noticed that the use of comic books as a teaching resource is powerful, as the experiences the students had in class go by the "rational" and "sensitive" (emotional) knowledge. This kind of experience tends to mobilize the students' relation of affection about the knowledge of the body and the bodily practices.

The education for leisure with the use of super heroes' comic books begins with the idea that the characters are part of a range of products and activities which are consumed by people in their free time (comic books, films, electronic games or toys). The purpose of such education is that as people use these activities in the context of leisure throughout their lives, they can be not only critical, but also creative about them.

The use of comic books as a complementary resource, coupled with the students' daily practices, can contribute with a more interesting and engaging Physical Education class. Therefore, we can say that its use can also contribute to decrease the number of school dropouts and increase the interest for Physical Education classes.

In this pedagogical experiment, based on what has been analysed and identified up to this moment, there is evidence that it has provided the students, who took part in the investigation with education for leisure, an awakening for enjoyment of elements that are part of the bodily culture of movement, and the access to some leisure contents herein represented, above all, by the physical, sportive and artistic aspects, in addition to the experience in class and construction of comic books. 


\section{REFERENCES}

ARROYO, M. G.. Fracasso-sucesso: o peso da cultura escolar e do ordenamento da educação básica. In: ABRAMOWICZ, A.; MOLL, J. (Org.). Para além do fracasso escolar. 6 ed. Campinas, SP: Papirus, 2003, p.11-26.

BRASIL. Ministério da Educação e do Desporto. Secretaria de Educação Fundamental. Parâmetros curriculares Nnacionais. primeiro e segundo ciclos do ensino fundamental. Brasília, DF: MEC/SEF, 1997.

BRASIL. Ministério da Educação. Secretaria da Educação Básica. Base nacional comum curricular. Brasília, DF, 2016. Retrieved from: http://basenacionalcomum.mec.gov.br/\#/site/inicio. Acess: Dec. 10, 2018.

BRASIL. A prática de esporte no Brasil. 2017. Retrieved from:

< http://arquivo.esporte.gov.br/diesporte/2.html >. Acess: May 11, 2017.

CARVALHO, L. A.; LOPES DA SILVA, C. O currículo do estado de São Paulo - Educação Física: considerações sobre a cultura corporal de movimento e o lazer. Revista Bras de Ciência e Movimento, Brasília, v. 23, n. 3, p. 14-29, 2015.

COHEN, R. H. P. A lógica do fracasso escolar: psicanálise \& educação. Rio de Janeiro: Contracapa, 2006.

DARIDO, S. D. A educação física na escola e o processo de formação dos não praticantes de atividade física. Rev Bras de Ed Física e Esporte, São Paulo, v.18, n.1, p. 61-80, jan./mar., 2004.

DAOLIO, J. Da cultura do corpo. Campinas, SP: Papirus, 1994.

FERRÉS PRATS, J. Las pantallas y el cerebro emocional. Barcelona: Editorial Gedisa, 2014.

FORTES, M. O. et al. A Educação Física escolar na cidade de Pelotas, RS: contexto das aulas e conteúdos. Revista da Educação Física. UEM, Maringá, v. 23, n.1, p. 69-78, jan./mar., 2012.

FRONZA, M. As possibilidades investigativas da aprendizagem histórica de jovens estudantes a partir das histórias em quadrinhos. Educar em Revista, Curitiba, n. 60, p. 43-72, abr./jun. 2016. LOPES DA SILVA, C. Una aplicación de cómics como recurso didáctico en las clases de Educación Física: un estudio a partir de la realidad brasileña. In: VI Congreso Redu, 2018, Ibarra - Equador. Libro de artículos VI Congreso Redu, 2018a. p. 272-279.

LOPES DA SILVA, C. Histórias em quadrinhos de super-heróis e educação para o lazer na Educação Básica. In: V Colóquio Educação Física e Ciências Sociais em Diálogo, 2018, Piracicaba e Guarulhos. Anais do $V$ Colóquio Educação Física e Ciências Sociais em diálogo, 2018b. p. 40-42. LOPES DA SILVA, C.; SCHWARTZ, G. M. ; SILVA, P. P. C. ; SILVA, L. F. ; RIGONI, A. C. C.; ROSSI FILHO, S. . Cultura corporal de movimento e histórias em quadrinhos nas aulas de Educação Física. In: 17a Mostra Acadêmica UNIMEP - $17^{\circ}$ Congresso de Pós-graduação, 2019, Piracicaba. Anais 17 a Mostra Acadêmica UNIMEP. Piracicaba: Editora UNIMEP, 2019a. p. 101-101.

LOPES DA SILVA, C.; ROSSI FILHO, S. ; RIGONI, A. C. C. ; SILVA, L. F. ; SILVA, P. P. C. ; SCHWARTZ, G. M. . Education for leisure and the use of comic books in Physical Education classes. 
In: BRICSCESS 2019, 2019, África do Sul. BRICSCESS Abstracts. África do Sul: The South African Journal of Sports Medicine, 2019b. p. 52-52.

LOPES DA SILVA, C.; ROSSI FILHO, S.; SILVA, P. P. C. ; SCHWARTZ, G. M.; SOUZA, M. F.; SOUZA, A. dos S.; SCALZITTI, A.; PILLON, R SILVA, L. F.; KIRNER, C.; RIGONI, A. C. C. Relatório de pesquisa I - Lažer, educação e tecnologia: construção de histórias em quadrinhos em aulas de Educação Física no Ensino Fundamental. Fundação de Amparo à Pesquisa do estado de São Paulo, 2019c.

MARCELLINO, N. C. Lažer e educação. 12 ed. Campinas: Papirus, 2004.

MINAYO, M.C.S. Ciência, técnica e arte: o desafio da pesquisa social. In: MINAYO, M.C.S. (org.). Pesquisa social: teoria, método e criatividade. Petrópolis, RJ: Vozes, 1994. p. 9-29.

MIRANDA, G. Maioria dos brasileiros está longe dos esportes. Jornal Folha de S. Paulo, São Paulo. Oct. 11, 2011. Retrieved from: http://www1.folha.uol.com.br/equilibrioesaude/988834-maioria-dosbrasileiros-esta-longe-dos-esportes.shtml. Acess: Jan. 18, 2013.

NAVARRO, L. et al. A dificuldade de aprendizagem e o fracasso escolar. Journal of Research in Special Educational Needs, London, v. 16 (S1), p. 46-50, 2016.

OLIVEIRA, R. C. Na 'periferia' da quadra - Educaşão Física, cultura e sociabilidade na escola. 2010. Tese (Doutorado em Educação Física). Departamento de Educação Física, UNICAMP, Campinas, 2010.

TENÓRIO, J. G.; SILVA, C. L. da. Educação Física Escolar e a não participação dos alunos nas aulas. Ciência em Movimento - Educação e Direitos Humanos, Porto Alegre, v. 15, n. 31, p. 71-80, 2013.

Recebido em: 14 de agosto de 2020. Aprovado em: 23 de setembro de 2020. 